УДК 821.161.2.09- 93

Варданян М. В.

кандидат філологічних наук

Криворізький педагогічний інститут ДВНЗ «Криворізький начіональний університет»

\title{
ЖАНРОВО-СТИЛЬОВА СВОЕРІДНІСТЬ «ДИТЯЧОГО» ДОРОБКУ ІВАНА БАГРЯНОГО
}

У статті досліджується «дитячий» доробок відомого украӥнського письменника Івана Багряного. 3 позииій жанрово-стильових особливостей розглянуто віриовані казки «Телефон» $i$ «Казка про лелек і Павлика-мандрівника», оповідання «До Ворскли, по рибу», вірші «Інженер», «Експромти» та пісню «Колискова» у контексті власної творчості письменника та в контексті доби.

Ключові слова: І. Багряний, «дитячий» доробок, жанр, стиль. 
В статье исследуется «детское» наследие известного украинского писателя Ивана Багряного. С позиций жанрово-стилистических особенностей рассмотрены стихотворные сказки «Телефон» и «Сказка об аистах и Павликепутешественнике», рассказ «К Ворскле, за рыбой», стихи «Инженер», «Экспромты» и песню «Кольбельная» в контексте собственного творчества писателя и в контексте эпохи.

Ключевые слова: И. Багряный, «детское» наследие, жанр, стиль.

The article explores the "children's» heritage of the famous Ukrainian writer Ivan Bahrianyi. From the positions of the genre and stylistic peculiarities were considered of the poetic tales of "Telephone» and "Tale of the Storks and Pavlik-traveler», short story "To Vorskla, to fish», rhymes «Engineer», "Impromptus» and the song "Lullaby» in the context of the writer's own creativity and in the context of the epoch.

Key words: I. Bahrianyi, «children's» heritage, genre, style.

Іван Багряний вагома постать у культурному світі, а його творчість для «дорослої» аудиторії займає одне з провідних місць у літературному процесі XX ст. Ось минуло 50 років від дня смерті письменника, поета, публіциста, громадського і культурного діяча, а його багатоманітні здобутки постійно привертають увагу критиків і читачів, що засвідчують як значні наукові праці про життя і діяльність митця (М. Балаклицький, В. Гришко, М. Жулинський, М. Ільницький, І. Качуровський, О. Ковальчук, О. Коновал, Г. Костюк, М. Сподарець, О. Тарнавський, Ю. Шерех, О. Шугай та ін.), так і видання його спадщини.

Проте маловідомий I. Багряний як «дитячий» письменник, твори якого для молодших читачів до недавно не перевидавалися, а тому не упорядковані й не вивчені дослідниками. Так казки були нещодавно передруковані «Смолоскипом» [Багряний Телефон 2011], [Багряний Казка 2011], інші тексти розпорошені по хрестоматіях із дитячої літератури, антологіях, збірках для читання та Інтернет сайтах. Скупими $є$ і згадки про Багрянові твори для дітей (Г. Костюк, О. Тарнавський та ін.), тому вповні уявити масштаби його спадщини для найменших доволі непросто. Цим і зумовлений вибір теми нашого дослідження, метою якого є розгляд жанрової своєрідності «дитячого» доробку І. Багряного у контексті власної 
творчості та у контексті доби. Не претендуючи на вичерпність дослідження, у цій статті робимо спробу відкриття ще однієї грані таланту I. Багряного як «дитячого» письменника, котрий написав свої твори для найвимогливішого читача - дитини.

Попри те, що життя подарувало I. Багряному чотирьох дітей: від першого шлюбу мав сина Бориса і доньку Наталю, у другому шлюбі з Галиною Слизарівною виховував Нестора і Роксолану, література для дітей і юнацтва не була основним засобом його самовираження, тому і спадок ним залишений не значний, але різножанровий. Це оповідання «Пацан» і «До Ворскли, по рибу», поезія «Рідна мова», «Рибалки», пісня «Колискова», вірші «Забіліла наша хата», «Інженер», «Експромти», марші «Піонери» і «Вперед, соколи!», казки «Телефон» і «Казка про лелек та Павликамандрівника» та ін. Вони не лише урізноманітнюють діаспорну літературу для дітей і юнацтва, представлену іменами С. Черкасенка, В. Винниченка, О. Олеся, К. Перелісної, В. Вовк, О. Лятуринської, В. Куліша, Л. Храпливої-Щур, Р. Завадовича, Л. Полтави та ін., а й вписуються у контекст «материкового» літературного процесу, засвідчують нероздільність «дитячої» літератури часовопросторовими межами.

За розпочатою Г. Костюком традицією, творчу біографію I. Багряного прийнято поділяти на чотири етапи: «Перший - від 1926 до 1932 року, тобто від початку його літературної праці до дня першого арешту. Другий період - від 1932 до 1940 року. Доба в’язниць і концентраків. Третій період - 1941 до 1945 року. Доба Другої світової війни й окупації України. Четвертий період 1945-63. Повоєнна доба й еміграція» [Багряний 2006: 569]. У такий розподіл вписується і спадок І. Багряного для дітей, що, водночас, інтертекстуально зв'язаний із творами письменника для «дорослої» аудиторії.

3 першим періодом пов'язані оповідання «Пацан» та вірш «Піонери», які не передбачалися для дітей. Рівно як і твори другого етапу «Рідна мова» і «Вперед, соколи!», вони були надруковані 
у цілком серйозних «дорослих» журналах «Всесвіт» $\mathrm{i}$ «Червоний кордон», або входили до авторських збірок. Проте означені художні тексти зараховують до кола дитячого читання. Так в оповіданні «Пацан» йдеться про дев'ятирічного хлопчика Кольку, життєва драма якого розгортається на фоні подій громадянської війни. За припущенням М. Балаклицького, «невідомо, до якої міри такі сумні пригоди тотожні його дитинству, проте присвята твору [«Моєму маленькому другові» - M. B.] вказує на те, що, цілком можливо, молодий І. Багряний дружив 3 подібними „пацанами”, добре знаючись на їхніх недитячих лихах» [Багряний 2006: 15]. Певно, на творчому задумі оповідання позначився і досвід роботи самого I. Багряного в колонії для безпритульних та сиріт. Водночас, теми дитячої безпритульності, участь і долі дітей за роки громадянської війни були на часі. Вони порушувалися у творах С. Васильченка («Приблуда») та О. Копиленка («Дівчинка 3 шляху»), А. Головка («Червона хустина», «Пилипко») та П. Панча («Білий фартушок»). Своєрідного відображення згодом ця тема здобуде у повісті «Пацани» В. Куліша, сина репресованого драматурга Миколи Куліша та діаспорного письменника, дитинство якого минало в буремні роки.

На межі двох періодів, імовірно, було написано й оповідання «До Ворскли, по рибу». Насамперед, споріднює тогочасні авторські тексти для різних адресатів ліричний пафос. Далі, захоплення I. Багряного риболовлею знайшло своє відображення у прозових i поетичних творах, у яких так чи інакше обіграється ця тема. Крім того, знаходимо згадки однодумців про творчі задуми письменника.

Про визрівання у митця ідеї про написання твору, присвяченого риболовлі на річці Ворскла, що на Полтавщині, відшукуємо у книзі Г. Костюка «Зустрічі і прощання», який так переказує міркування поета-початківця тодішнього ще студента Київського художнього інституту 1927 року на Дніпрі: «...рибальство - це [...] теж поезія... Можливо, колись щось напишу про це [....]. На Ворсклі. [...] Все моє дитинство на ній. Дід - знаменитий рибалка, а я його постійний помічник. Та то ціла поема. У двох словах не розповіс- 
ти» [Костюк 2008: 239]. Як бачимо, I. Багряний був вірний своєму слову, адже незабаром виходять друком похмурий твір «3 оповідань старого рибалки» (1927) і поезія «Рибалки» (1929). В останній оспівується краса природи рідного краю, уславлюється сивий дідусь, який навчає рибалити онука Івася, певно, що ці образи навіяні спогадами зі щасливих моментів дитинства.

Зрештою, і в оповіданні «До Ворскли, по рибу» наявні біографічність та інтертекстуальність, що є домінантною стильовою рисою творів і письменників-експатріантів, як-от В. Винниченка, У. Самчука, С. Маланюка. Зокрема, у вказаному тексті актуалізується пам'ять дитинства, а ліричним настроєм воно поєднується 3 поезіями другого етапу творчості «Матері» і «Рідна мова», що, за виразом М. Балаклицького, стали своєрідним бажанням утекти у світ спогадів і фантазій.

У «До Ворскли, по рибу!» письменник поринає в ідилічний світ дитинства, зображуючи гармонійні стосунки батька Максима 3 «помічником і приятелем» сином Борисом (можливо прототип першого сина I. Багряного? Або проекція на власне дитинство?). Герої босоногі, в обідраній одежині, але об'єднані спільним захопленням. Вони дружньо і весело ідуть «в луг, десь до Ворскли, по рибу», несуть рибальські знаряддя сак і хрокало, складають декламації, спостерігають за пташкою, милуються рідними краєвидами Силенковим перевалком, ярмарковою площею, знайомими вуличками, золотим піском, синіми борами, червоною шелюжиною, духмяними килимами чебреців. У такий спосіб автор акцентує на порозумінні і спілкуванні дорослого і дитини, сина і батька, які мають пізнавати світ разом: «Вони дивилися на буйний мерехтливий світ, вбираючи його в себе. І так, витріщившись на той буйний світ очима, вони йшли, як по велетенській картині Врубеля, по золотій ярмарковій площі, занурюючи босі ноги в гарячий пісок до болю рідної, прекрасної, благословенної землі» [Багряний 2005: 295]. Автор стверджує життя, сповідує ідею цінності Людини, наповнює твір оптимістичним і патріотичним пафосами - любити 
життя, близьких, рідну землю: «С м іє т ь я... В і д п е р е п о вн еного с ерця... В і д над мі ру щ а с т...»[Багряний 2005: 295].

Сповнені патріотизму і покликані підняти національний дух за часів війни і окупації повість «Тигролови» і поема «Гуляйполе». Разом $з$ тим, І. Багряний на третьому етапі своєї творчої біографії пише і «Казку про лелек та Павлика-мандрівника» (1943), у якій йдеться про серйозну та украй важливу тему: шанобливе ставлення до рідного краю. Ця патріотична проблематика широко представлена в українській літературі для дітей, візьмемо хоча б вірші Д. Павличка «Де найкраще місце на землі», П. Воронька «Облітав журавель» та прозову казку I. Савицької «Де найкраще місце на світі?». Про повернення птахів 3 далекого краю до рідної домівки I. Багряний писав і у своїй ранній поезії «Над полем ключі журавлині...» (1929).

Дещо іншу тему ставить I. Багряний у ще одній своїй віршованій казці «Телефон», яка була написана через 13 років. Така увага письменника до вибору жанру казки не є випадковою, адже остання - то найпопулярніший і найбільш затребуваний жанр дитячої літератури. У жанрі віршованої казки творили радянські (українські й російські) письменники О. Іваненко, Н. Забіла, В. Симоненко, В. Маяковський, С. Маршак, К. Чуковський, письменники діаспори - О. Олесь, Л. Полтава, Р. Завадович, В. Радзикевич та ін., які через фантастичні, або вигадані образи ставили у своїх творах вагомі морально-етичні й патріотичні теми.

Містять мораль та мають пізнавальний характер i казки I. Багряного, які розраховані на дітей молодшого шкільного віку, що позначилося на їхніх жанрових особливостях. Насамперед, для кращого сприймання художніх текстів письменник поділяє їх на розділи. Крім того, І. Багряний, художник за освітою, оздоблює книги власними ілюстраціями - яскравими і великими, які переважають над змістом, що посилює образність викладу. Мова творів легка і доступна для сприйняття дітьми цієї вікової категорії, вод- 
ночас багата на художні засоби, що реалізує комунікативну функцію літератури. У такий спосіб, через зрозумілі для дитини образи і засоби, письменник ставить та розкриває важливі й доволі серйозні проблеми, що виконувало освітню роль.

Виховувати у нащадків любов до Батьківщини І. Багряний прагнув через свою глибоко патріотичну «Казку про лелек та Павлика-мандрівника». Він хотів бачити підростаюче покоління національно свідомим і духовно багатим. Тому головним героєм твору $\epsilon$ маленький хлопчик Павлик, якого автор характеризує як сміливого, відповідального, порівнює $з$ козаком-молодцем, називає козаком завзятим. Його вік наближений до категорії дітей, на яких розрахована книга. Вони разом вчаться пізнавати світ, шанувати рідний край, батьків, традиції.

Задля цього образ персонажа подано у динаміці подій, що супроводжуються моральним аспектом і фольклорною образністю. Відтак казка складається з шести розділів. У першій частині показано прощання лелек із Україною і Павликом, якому даються настанови слухатися матусю, у другій - ідеться про моральне зростання Павлика, який рятує лелеченят від вовків. Цим відважним порятунком хлопчик завойовує довіру і пошану у птахів, які відтепер вважають його другом. Автор піднімає виховні й етичні теми у кращих традиціях етнопедагогіки, заохочуючи дітей бути як Павлик слухняними, хорошими, чемними, розумними, сміливими, шанувати батьків, любити рідних і Вітчизну, тваринок і пташок. Також I. Багряний будить у читача патріотичні почуття, підсилюючи думки використанням традиційної української образності, зокрема пейзажів (білі хатки, сади строкаті, степи широкі, левади) і образів лелек як животворних символів-оберегів, народної моралі (шанування батьків, звичаїв), ритмомелодики, що наближена до фольклорних ліричних пісень.

3 лелеками пов'язаний основний зміст казки. У їхніх образах автор утілив народні уявлення про птахів, які приносять весну в країну, дарують щастя і є охоронцями роду, гніздяться на подвір'ях 
шанованих господарів, наводять лад у родині. Схожі мотиви зустрічаємо і в оповіданні Є. Гуцала «Перебите крило».

У своїй казці І. Багряний прагне довести, що основою духовного життя є рідна земля. Тому вдається до контрасту. Не схожою до України як кліматом, так і флорою та фауною постає Африка, якій присвячено наступні три розділи казки, де розповідається про подорож Павлика до чужих земель, його перебування у Африці й сум за Вкраїною, від’їзд хлопчика і його прощання з тваринами.

Письменник розгортає цілу панораму невідомої, загадкової країни. За вимогами казки, його тварини - слони, крокодили, гіпопотами, мавпи, жирафи, страуси, зебри, носороги, акула - персоніфіковані, тому радо зустрічають і втішають хлопчика, коли він сумує, проводжають у дорогу, дарують подарунки другу, просяться теж до України. Тим самим автор не лише знайомить читача з екзотичними тваринами, а проводить думку про єднання людини 3 природою.

Проте домінантним є патріотичний зміст. Вже перша зустріч iз Африкою, такою несхожою до рідної України, приносить Павлику не очікувану радість, а розчарування: «Так оце та Африка?! // Так оце той вирій?! // Ходить, ходить сонечко // По пустелі сірій. // Попереду - море, // А позаду - гори, // Межи ними один пісок, // Горе ж мені, горе!» [Багряний Казка 2011: 28]. У такий спосіб Павлик усвідомлює найголовнішу істину про рідну Батьківщину, про що йдеться при поверненні до України і зустрічі з близькими у завершальному розділі. Відтак своєрідним рефреном і лейтмотивом твору постають рядки: «Бо немає краще, як на Україні!». I невипадково автор уводить до твору ще одну деталь у сцені поверненні птахів з Африки: «І сміються збоку // Радісно лелеки, // Як усі питають // Про краї далекі» [Багряний Казка 2011: 43]. Адже, за канонами жанру, що передбачає повчальність, І. Багряний у своїй казці спонукає замислитись над тим, що краще за рідний край ніде немає, прагне прищепити почуття гордості за нього і пошану до батьківської домівки, бо збереження духовних багатств - то запо- 
рука майбутнього України і роду. Про це письменник постійно мріяв, подібні міркування пронизують усю його творчість. Відчуття І. Багряного підсилювалися переслідуваннями влади, ув'язненнями, репресіями, переховуванням і втечами, а також постійною розлукою зі своєю родиною - дружиною і двома дітьми Борисом $і$ Наталкою. Можливо, для них і була ця книжечка, як значиться у присвяті «Подарунок маленьким», бо вже 1944 року I. Багряний емігрує без родини безповоротно.

З 1946 року постійним місцем перебування для письменника стає містечко Новий Ульм у Німеччині, а з 1948 до останнього дня життя 25 серпня 1963 року І. Багряний завсідник шпиталів. У цей період напише різножанрові твори - п’єси «Генерал», «Морітурі», «Розгром», романи «Людина біжить над прірвою», «Огненне коло», «Маруся Богуславка», «Сад Гетсиманський». Для дітей складе «Забіліла наша хата», «Інженер» (1954), «Експромти» (1954), «Колискову» (1955), «Телефон» (1956).

Вже згадувана казка «Телефон» була написана у санаторії Блазієн у Шварцвальді Західної Німеччині, де письменник лікувався від туберкульозу і був ізольований від нової родини - коханої дружини та маленьких діточок Нестора і Роксолани. Попри те, що твір інтертекстуально пов'язаний із однойменною казкою К. Чуковського «Телефон» (1926), водночас відчутна співзвучність із казками В. Симоненка «Цар Плаксій і Лоскотон» і Л. Полтави «Казка про Чародія-Лиходія, Івасика-козачка і чорне море», де через алегоричні, контрастні образи злотворців і добротворців, оптимістичну кінцівку проходить патріотична ідея про існування майбутньої України як квітучої, самостійної і щасливої країни.

Композиція і символіка Багрянівського «Телефону» порівняно $з$ Чуковським складніша. Казка російського письменника, який був обізнаний з англійською літературою для дітей і часто іiі перекладав, наближується до пісеньок-лимериків, віршиків-нонсенсів Едварда Ліра, де, як правило, йдеться про якусь неймовірну чи веселу подію з іронічним пафосом і грайливою формою. У казці 
К. Чуковського відсутній динамічний сюжет, а каламбурні, нісенітні телефонні розмови пов'язані з образом лікаря. Це така собі гра у зіпсований телефон, що спонукає дитину до запам'ятовування.

На перший погляд, казка українського письменника $\epsilon$ переспівом Чуковського «Телефону». А якщо подивитися глибше, згадати, що основним мотивом творчості І. Багряного було розвінчання тоталітаризму і національне питання, то під побутовизмом $\mathrm{i}$ розважальністю виявиться прихований соціальний сенс, що визначав напрям радянської та еміграційної дійсності. Це дає підстави означити жанр твору як символічна віршована казка.

«Телефон» І. Багряного має динамічний сюжет та складається 3 двох частин, що розмежовуються часом розмов оповідача з тваринами - перша вночі, друга вранці, але об'єднуються повторювальним закінченням. Убачаємо в цьому певну символізацію. Перша частина сповнена песимістичним пафосом («захрипли наші тати»). Як ознакою нездорового світу є скарги звірів на хвороби. Автор подає цілий перелік лікарських засобів від неврології, голови, горла, різних розладів організму - пірамідон, рицина, хінін, аспірин та ін., що, ймовірно, пов'язано з хворобою і лікуванням самого письменника. Це така собі символізація розпачу, зневіри, визнання поразки у боротьбі за ідею.

Друга ж частина казки - це уособлення надії, сподівання на перемогу молодших поколінь, яких автор іменує «новобранцями». Тут наявний бунтівний, войовничий пафос. У той час письменник створює образ Поета, місія якого чути народ і бути його голосом. У такому контексті прочитується образ оповідача, символ телефону та післямова казки про безупинність життя.

Водночас своєрідними міні-історіями, які розказують тварини оповідачу, $\epsilon$, вміщені у двох частинах, 17 розділів казки. Здавалось би, жартівливі розповіді про усілякі нісенітниці покликані розважити дитину, але символіка образів тварин і оповідача, інакомовлення підштовхують думати, що в іронічній формі викривається тогочасна авторова дійсність, де люди живуть у незгоді 3 
суспільством. I знову I. Багряний у властивій для нього формі ставить у центрі Людину, яка перебуває у єдності з природою і незлагоді з суспільством. Тому не випадково письменник звертається до образу тварин. Саме вони з давніх часів вважалися супутниками людини. Та й казки про тварин - $є$ найпершими, $з$ якими дитина починає пізнавати світ і засвоювати моральні норми.

У «Телефоні» подано дивне плетиво африканських і українських образів тваринного світу: слони, носороги, страуси, жирафи, журавлі, кенгуру, крокодили, зайча, гіпопотами, вовченя, зебри, горили, шимпанзе, лелеки, мавпи, мишеня, олень. Їх значно більше ніж у К. Чуковського та й у першій казці самого I. Багряного. Проте їхнє розташування у розділах не є довільним. Через образи тварин автор ставить проблеми соціальної дійсності та еміграційного оточення. Вони постають своєрідними образами-символами у розкритті ідеї.

Очолює казку розповідь про слона, для якого слоненята просять вислати трубу. Існує думка, що слону, який знесилено падає $\mathrm{i}$ «трубить» про порятунок, допомогти підвестися може лише слоненя. Слон як уособлення мудрих правителів, сили і міцності, є алегорією людей старшої когорти, які, втомлені кричати про негаразди, упали духом, зламалися морально чи фізично, а допомогти їм можуть молодші покоління.

Попри те, що носоріг є грізною і безстрашною твариною, яку боїться навіть тигр, у творі він уособлює зневірену і зламану людину: «Я прошу Вас, поможіть // I рецепта напишіть, - // Напишіть як слід, поволі, // Пропишіть в нім щзастя - долі... // Ну тієї щзастя-долі, // Випікати чим мозолі» [Багряний Телефон 2011: 9]. Закликом-докором лунають слова оповідача до носорога-ватажка, пана Загреби, бути невразливим, не здаватися та боротися: «Piг такий носити треба! // Рити трунт, ламати ліс, - // Ось для цуього такий ніс» [Багряний Телефон 2011: 10].

Уособленням заляканої людини постає страус, фізіологія якого передбачає ховання голови у пісок, а прохання: «Вишліть 
темні окуляри! // Щоб не бачив я біди // Та й гуляв сюди й туди» [Багряний Телефон 2011: 12], - розкодовуються як нестерпність бачити невтішні факти соціальної дійсності.

Прозорливу, далекоглядну, але таку, що вже не вірить у покращення, українську політичну еліту уособлюють граціозні довгошиї жирафи, які просять парасолі: «Бо ми тута ходим голі! // Дощ, страшний такий іде, // Не сховати нам ніде // Бідну голову свою - // Ні в діброві, ні в гаю ... // Нам циих довгих ший не треба // Досягають аж до неба!» [Багряний Телефон 2011: 13-14].

Зневіра української еміграції на повернення пов'язана і з образом журавлів, які просять нові крила: «Вишліть нам швиденько крила... // В Україну ми летіли, // Свої крила потомили // I тепер не має сили // Повернутись взагалі // Вже до рідної землі» [Багряний Телефон 2011: 15]. У цих рядках втілена мрія багатьох експатріантів про Україну. А прощальне курликання журавлів «Ой курлікурлю-курлі!» уособлює безмежну тугу за рідним краєм. Нові крила - символ повернення додому зі свіжими силами.

Голосить про трагедію кенгуру як уособлення гарної матері, котра втратила своє дитя - символ майбутнього руху вперед і прогресу: «Чим зашити цุю діру?» [Багряний Телефон 2011: 17]. Кричать щосили спритні й хитрі крокодили про біду і драму, бо не можуть вже протистояти навколишньому світу, рухатись усупереч канонам і укладам суспільства. Втомленими від переслідувань і хворими постають люди, які уособлюють спритних зайців, котрі гуляли у «квача».

Завершує першу частину казки розповідь гіпопотама (бегемота), який традиційно уособлює грубу і руйнівну силу. Цей образ часто зустрічається у літературі, зокрема, кіт на прізвисько Бегемот зображений у «Майстері й Маргариті» М. Булгакова. Бере участь в есхатологічному двобої демон Бегемот у «Битві» Р. Шеклі. У Біблії бегемот постає монстром, який очікується в кінці світу. Так і в казці І. Багряного гіпопотам, названий «конище-водянище», об’ївся 
очерету і страшно хрипить, що може сповіщати про закінчення певного відрізку в історії України, але не ії руйнування.

Бо вже друга частина казки розпочинається бадьорим настроєм. Тут з'являються вовченята як уособлення хоробрості й перемоги. Це молоде покоління, так звані «новобранці». Алегорично звучить їхнє звертання до старших авторитетів, яким поставав i сам I. Багряний в еміграції для нової генерації українських письменників: «Вишліть ноти для пісень! // Хочем знати, як співати, // Бо захрипли наші тато // I не можуть научати // А ми хлопщуі голосисті, // Тенористі і басисті, // Як ми ноти занотуєм, // Як заграєм! Як почуєм, - // От тоді замаршируєм...» [Багряний Телефон 2011: 27-28].

Не хочуть мовчати, готові говорити на повний голос, викривати владу, яку втілює лев, і смугасті зебри: «Хай трепече левдракон - // Я вже маю телефон!» [Багряний Телефон 2011: 29]. Здатність зебри переносити неволю, але не приручатися, та іiї забарвленість пов'язують цей образ із колишніми політв'язнями, яких не здолала неволя, готових сказати правду про владу, боротися 3 нею, що закодовано у таких рядках: «Тута зебра-королева! // Заберіть в звіринець лева! // Що? Немає клітки в мірку? // Заберіть тоді до иирку! // Місия й там нема йому? // Заберіть тоді в тюрмy-y-y!!» [Багряний Телефон 2011: 30].

До образу мавпи I. Багряний звертається тричі, що має таке тлумачення: горила, яка кричить нерозбірливою мовою і має величезну силу - прагнення поета стати зрозумілим, бути почутим, аби впливати на громадську думку; кмітлива шимпанзе з люстерком, яка воліє існувати хоч і в зоопарку, але зі своїми близькими - наміри жити і не тікати, правдиво відображати життя і бути потрібним своїй родині і нації; допитливі мавпенята - уміння пристосуватися до обставин, аби їх змінити: «Ми беремо участь в балі ... // Я-а-к ушкваримо!» [Багряний Телефон 2011: 37-38].

Про конфронтацію поколінь в еміграційному середовищі повідомляється через образи лелек і жабенят: «Ой, всі жаби збунту- 
вались! // Збунтувалась вся голота // А найпаче ті малята, // Ti крикливі жабенята, // У гармати загриміли - // Не хотять, щзоб ми їх їли...» [Багряний Телефон 2011: 36]. Автор веде мову про вирування активності у молоді, конфлікт поколінь. Тому він радить ворогувати не одним із одним, а супроти справжніх недоброзичливців: «Ліпше ви тікайте з лук, // Не робіть маленьких мук. // Ліпше їжте ви гадюк» [Багряний Телефон 2011: 36].

Завдання ліквідувати псевдолітературу покладено на мишку, яка скаржиться на кота через його перешкоди у знищенні книг. Такою є порада оповідача: «Ось адрес аж изіла книжка, - // Вже котові буде кришка!» [Багряний Телефон 2011: 40], що звучить як заклик до руйнування і цієї стіни на шляху до свободи слова і гласності.

Символічним $\epsilon$ закінчення казки знайомством 3 оленем: «Знаю й так всі ваші болі - // Ви хотіли б діжку солі...» [Багряний Телефон 2011: 42]. Традиційно ця тварина уособлює боротьбу зі злом та силу духу, а фразеологізм з'їсти діжку солі як витрачання багато часу і сил на досягнення порозуміння. Тож автор цим образом показує, що слід не падати духом, а наполегливо іти вперед до реалізації заповітної мрії на благо Вітчизни, попри всі перешкоди. Такою є ідея казки. Тому і возвеличується І. Багряним сучасний здобуток людства - телефон («Слава, слава телефону!») як символ гласності незалежно від раси, країни, віри і походження.

До сучасної і популярної теми освоєння різноманітних професій звертається І. Багряний у сюжетному вірші «Інженер». Як видно з контексту творів діаспорних письменників, література для дітей $\epsilon$, так би мовити, профорієнтаційною. Про моряків знаходимо у Р. Завадовича «Малі моряки» та І. Савицької «Я хочу бути моряком», льотчиків - у Л. Полтави «Всі полинем», астронавтів у Р. Завадовича «Шляхом астронавта» та Л. Храпливої-Щур «Пісня зореплавців». У І. Багряного професія інженер є засобом іронії у розкритті образу хлопчика. Тому в ідейному плані цей вірш співзвучний із поезією С. Маршака «Майстер-ламайстер», де основна 
думка вміщена у заключних рядках: «Ти у нас не майстер, ти у нас ламайстер». Так і хлопчина 3 «Інженера» настільки виявляв незадоволення своїми іграшками перед татом і так їх лагодив, що залишився з нічим: «I сумує він тепер, // I стоїть, як інженер. // Забавки були - й немає!» [Багряний Інженер 2011: 511].

Образ хлопчика і тата зустрічаємо і в «Експромтах»- невеличких лагідних віршиках, адресованих сину Нестору. Через хворобу I. Багряний не міг бачитися з родиною, але надсилав із санаторію свої поетичні вітання улюбленому сину листами: «Хлопчик маленький, // Песик біленький // I горобчик без хвоста - // Написали листа. // Хлопчик припечатав - // Посилає до Тата. // A Тато чекає, чекає, - // А від Несторика листа немає, // I журиться Тато, чи скоро // Напише листа й Несторик» [Багряний Експромти]. У цих рядках відчутна турбота і сум батька про свого сина, виховання якого було важливим, але неможливим для I. Багряного.

У «дитячому» доробку митця $\epsilon$ і колискова пісня. Вона присвячена Андрію Китастому, сину відомого композитора, диригента, бандуриста Григорія Китастого, з яким І. Багряний товаришував і співпрацював. Письменник написав кілька патріотичних віршів, які композитор окрилив, зокрема це такі пісні на вірші як «Вперед, соколи..», «Марш молоді», «Пісня про Ю. Тютюнника», «Юнацька», «Вставай, народе...», «За горе народу...» та ін. Певно, до річниці сина Г. Китастого і була написана «Колискова».

Вказана пісня відповідає вимогам, які висуваються до такого жанру фольклорних творів: $є$ адресат дитина і виконавець матір, у творі чимало риторичних звертань («мій зайчик», «сину мій», «маленький», «моя зірка золота» тощо), зменшувально-пестливих слів (синочок), що виражають ставлення матері до дитя, а ніжні слова «лю-лі-лю» та асонансна група «а-а-а» створюють довірливу атмосферу між ними. У творі письменник вдається до сталої символічної української образності - сокіл крилатий, місяць золотий тощо. Лунають слова-заклинання кращої долі для дитини, що виконують морально-етичну роль: «Будеш ти, як дуб, високий, // Чорнобри- 
вий, ясноокий, // I сміливий, як Богдан, // I своєму слову пан, // I, як лицар, хоробрий, І до матінки добрий...» [Багряний Колискова].

Проте і в жанрі дитячого фольклору I. Багряний не зраджує собі. Його твір несе патріотичний зміст. Перебуваючи в еміграції, жив Україною. Слушно зауважив О.Тарнавський: «...здавалось, що письменник перебуває не на чужині, але в рідному краї, віддихає тим самим повітрям, що наші люди в Украӥні, турбується тими самими проблемами, щзо найактуальніші для нашого народу в Україні, і його кожне слово - це відзвук-співчуття чи протест на те, щзо твориться в Украӥні» [Багряний 2006: 607]. Так і в «Колисковій» викривається соціальна дійсність, засуджується зрадництво, наклепи, зло, звучить заклик любити рідну землю та шанувати батьків.

Колискова пісня пройнята сумом і ностальгією за Україною: «Серием лину ж в Украӥну... // 3 неї ми в світи пішли, // Всі моря перепливли, // Тільки ж серцем там лишили // I забути не змогли». У цих рядках втілюється мрія І. Багряного про повернення на Україну, чому не довелося здійснитися. Тому-то своєрідним заповітом до нащадків звучать слова про залучення до своїх коренів: «Будеш ти щзасливий, сину, // I на вільну Батьківщину - // В край, де ми на світ взялись, // Ти повернешся колись». Безумовно, що «Колискова» I. Багряного написана в кращих традиціях літературних колискових пісень Т. Шевченка, С. Руданського, В. Сосюри.

Образок $з$ дитинства виринає і в зимовому етюді «Забіліла наша хата», надрукованого поза збірками [Багряний Забіліла]. Початок зими в природі та пов'язані з цим приходом емоції у дітей зображували у своїх поезіях М. Рильський «Білі мухи», П. Воронько «Дідів портрет», Л. Полтава «Зимовий сад», К. Перелісна «Заворожений сад», В. Симоненко «Снігу, снігу...» та ін. Так і поезія I. Багряного несе позитивний заряд. Ліричний герой поринає спогадами у дитинство, з його очікуванням чогось загадкового, феєричного від настання зими, з розвагами ліплення снігової баби. Медитація досягається і завдяки рецептивним зоровим образам 
засніженої хати, завірюхи, лугової стежини. Відтак затишна картина початку зими є нагадуванням про рідну домівку, згадкою про Вітчизну, яку кожен береже у своєму серці.

Підсумуємо сказане. І. Багряний залишив невеликий, проте різножанровий спадок для дітей. У центрі його віршів, оповідань, казок, пісень - світ дитинства, актуалізованого власною пам'яттю, або пов'язаного зі своїми синами. Пізнання світу дитиною відбувається разом з батьком, або завдяки тваринам, подорожам, іграшкам у кращих традиціях народної моралі. Уяскравлюють сприйняття оточуючого дитину світу ілюстрації, зроблені І. Багряним власноруч.

Водночас письменник порушує у своїх творах для дітей серйозні теми про теперішнє і майбутнє рідної Вітчизни, ставить у центр розповіді образ Людини, яка єднається з природою і рухається усупереч незлагодженим канонам суспільства. Тим самим його набуток для дітей вписується у контекст творів радянських і діаспорних письменників того часу та перегукується із власною творчістю. Все це дає можливість означити стильові особливості творів для дітей І. Багряного як біографічність, патріотичність, народність (етнографічність), соціальна спрямованість та інтертекстуальність.

\section{БІБЛІОГРАФІЯ}

Багряний 2005 - Багряний І. До Ворскли, по рибу: Оповідання // Дивосвіт «Веселки» : антологія літератури для дітей та юнацтва: В 3 т. / Упор.: І. Т. Бойко; Б. Й. Чайковський, С. О. Герейло та ін. - К. : Веселка, 2005. - . Т. 2 : Українська література. - 2005. - С. 293-295.

Багряний 2006 - Багряний І. Вибрані твори / Упоряд., автор передм. та приміток М. Балаклицький /І.Багряний. - К. : Смолоскип, 2006. - 687 с.

Багряний Телефон 2011 - Багряний І. Телефон / Іван Багряний. - К. : Смолоскип, 2011. -48 с. : іл.

Багряний Казка 2011 - Багряний I. Казка про лелек та Павлика-мандрівника / Іван Багряний. - К. : Смолоскип, 2011. - 48 с. : іл.

Багряний Інженер 2011- Багряний I. Інженер // Українське дошкілля : [збірка для читання і розповідання дітям старшого дошкільного і молодшого шкільного віку] / Упор. Н. і О. Зінкевичі; передм. А. Погрібного. - 8-ме вид. - К. : Смолоскип, 2011. - С. 511. 
Багряний Експромти - Багряний I. Експромти [Електронний ресурс] / I. Багряний. Режим доступу до твору : http://ua.convdocs.org/docs/index-63455.html?page=4 Багряний Колискова - Багряний I. Колискова [Електронний ресурс] / I. Багряний. Режим доступу до твору: http://www.poetryclub.com.ua/metrs_poem.php? poem $=16304$

Багряний Забіліла - Багряний I. Забіліла наша хата [Електронний ресурс] /

I. Багряний. - Режим доступу до твору: http://ukrlife.org/main/evshan/ 25poetiv16.html

Костюк 2008 - Костюк Г. Зустрічі і прощання: спогади у двох книгах / Передм.

М. Жулинського. - К. : Смолоскип, 2008. -. Кн. 1. - 2008. - 720 с.

Статтю отримано 2 вересня 2013 р. 